\title{
Molecular analysis of a haplosporidian parasite from cultured New Zealand abalone Haliotis iris
}

\author{
Kimberly S. Reece*, Nancy A. Stokes \\ School of Marine Science, Virginia Institute of Marine Science, College of William and Mary, Gloucester Point, Virginia 23062, USA
}

\begin{abstract}
In the Austral summer and autumn of 2000 and 2001, mortalities of black-footed abalone Haliotis iris (Martyn, 1784) occurred in a commercial facility in New Zealand. Histological analyses suggested that infection by a haplosporidian parasite was responsible. To confirm identification as a haplosporidian and to help determine if this parasite represented a new, undescribed species, DNA was extracted from infected host tissues scored as positive for infection by histological examination. Small-subunit rRNA (SSU rRNA) gene sequences from both the host abalone and a parasitic organism were amplified by PCR and characterized. Although the sequence for this parasite was novel, not matching any known SSU rRNA gene sequences, phylogenetic analyses strongly supported grouping this parasite with the haplosporidians. Parsimony analyses placed the parasite at the base of the phylum Haplosporidia, ancestral to Urosporidium crescens and the Haplosporidium, Bonamia, and Minchinia species. Sequencing of multiple parasite DNA clones revealed a single polymorphic site in the haplosporidian SSU rRNA gene sequence.
\end{abstract}

KEY WORDS: Haplosporidian $\cdot$ Abalone $\cdot$ SSU rDNA $\cdot$ Parasite $\cdot$ Molecular phylogenetic

\section{INTRODUCTION}

Black-footed abalone Haliotis iris (Martyn, 1784), locally known as paua, is a valuable shellfish for both recreational and commercial fisheries in New Zealand. Due to demand that exceeds the $1400 \mathrm{t}$ annual limit on commercial fisheries catches (Annala et al. 2000), there has been increased interest in aquaculture of this species. A primary concern for growers of aquaculture species is disease management. Virulent pathogens of both cultured and wild abalone have been found around the world. A Rickettsia-like bacterial species was identified as the agent of withering disease in abalone Haliotis spp. on the west coast of the United States (Gardner et al. 1995, Friedman et al. 2000) and amyotrophia of Japanese black abalone Nordotis discus discus is thought to be due to a virus (Nakatsugawa et al. 1999). Protozoan parasites of the genus Perkinsus have been found in both greenlip Haliotis laevigata and blacklip abalone $H$. rubra from Australia (Lester \& Davis 1981, Goggin \& Lester 1995). The only formally described disease to date of $H$. iris is report- edly caused by a fungal pathogen (Grindley et al. 1998).

Haplosporidians are protozoan parasites found in invertebrates around the world in both marine and freshwater environments. Many species are pathogens of commercially important mollusks, affecting both wild and hatchery populations. Urosporidium crescens, a hyperparasite of a trematode found in the American blue crab Callinectes sapidus, causes unappealing dark blemishes in the meat referred to as pepper crab disease. Although not harmful to the crabs or to humans who consume them, pepper crab disease has economic impacts on the seafood industry (Perkins 1971). Haplosporidium nelsoni is the agent of the highly pathogenic MSX disease in the eastern oyster Crassostrea virginica. This haplosporidian was evidently introduced to the east coast of the USA by importation of infected Pacific oysters (Burreson et al. 2000) and has had devastating effects on wild oyster populations and hampered oyster aquaculture development in the region (Andrews 1966, Ford \& Haskin 1982). Haplosporidium costale, the agent of SSO dis- 
ease, is morphologically similar to $H$. nelsoni and has been responsible for mortalities of eastern oysters in seaside embayments of the US mid-Atlantic coast (Andrews et al. 1962). Bonamia ostreae, pathogenic in the European flat oyster Ostrea edulis, has devastated the flat oyster industry in Western Europe. Katkansky et al. (1969) reported a 'microcell' parasite that resembled B. ostreae in O. edulis from California. Elston et al. (1986) later traced B. ostreae in France to importation of oysters from California. More recently, this parasite was also found on the east coast of the United States (Friedman \& Perkins 1994), presumably by introductions of infected $O$. edulis from the west coast. Bonamia exitiosus, morphologically similar to $B$. ostreae, is pathogenic to the dredge oyster Ostrea chilensis in New Zealand (Hine 1991, Hine et al. 2001). Both species of Bonamia were tentatively considered haplosporidians despite the apparent absence of sporulation during their life cycles (Pichot et al. 1980, Hine \& Wesney 1992, Hine et al. 2001) and molecular evidence has recently confirmed their inclusion in the phylum Haplosporidia (Carnegie et al. 2000, Cochennec et al. 2000).

Histological examination of cultured abalone from a New Zealand aquaculture facility experiencing mortalities suggested the presence of a haplosporidian parasite, although no spores were observed (Hine et al. 2002, Diggles et al. 2002). Molecular genetic analysis was performed using SSU rDNA obtained from infected abalone to further characterize this organism.

\section{MATERIALS AND METHODS}

DNA isolation and PCR amplification. DNA was isolated from epipodium tissue of 5 infected Haliotis iris individuals ( 2 animals received in September 2000 and 3 animals received in February 2001) using the protocol for animal tissues of the DNeasy tissue kit (Qiagen). Initially, genomic DNA was amplified by PCR with universal primers for the small-subunit rRNA (SSU rRNA) gene (Medlin et al. 1988), with the polylinker bases removed and primers then designated as 16S-A and 16S-B. Reaction conditions and amplification parameters were as previously described, except that $400 \mathrm{ng}$ $\mathrm{\mu l}^{-1}$ bovine serum albumin was added to the reaction mixtures (Stokes et al. 1995). PCR amplification was also attempted using PCR primers (HAP primer set; Renault et al. 2002) that were previously designed to amplify a wide range of haplosporidian species (Renault et al. 2000). In addition, PCR amplification was attempted using a primer designed to target a SSU rRNA gene sequence that was common to Urosporidium crescens and an undescribed spot prawn parasite (Reece et al. 2000). This primer (UroComp280SSU, 5'-
GCCATGCGATCCGAACARTTA-3') was used in conjunction with the universal primer 16S-A (Medlin et al. 1988). PCR conditions were the same for amplification with primers 16S-A and 16S-B. After partial sequences were obtained for the parasite, specific internal primers were designed in order to complete the SSU rRNA gene sequence. These primers, NZAH-F4 (5'-ATTTGGTTTACTATCGGAATGAGAAC-3') and NZAH-R1 (5'-CTGTAGAGATGATTGACCTGATTG3 ), were paired with the universal primers $16 \mathrm{~S}-\mathrm{B}$ and 16S-A, respectively. PCR reaction mixtures were the same for primers $16 \mathrm{~S}-\mathrm{A}$ and $16 \mathrm{~S}-\mathrm{B}$, except that the buffer for 16S-A + NZAH-R1 was $60 \mathrm{mM}$ Tris-HCl, $\mathrm{pH}$ 9.0, $15 \mathrm{mM}\left(\mathrm{NH}_{4}\right)_{2} \mathrm{SO}_{4}, 2 \mathrm{mM} \mathrm{MgCl}{ }_{2}$ (Buffer F, Invitrogen Life Technologies). Cycling parameters with the parasite-specific primers were as follows: an initial denaturation of $4 \mathrm{~min}$ at $94^{\circ} \mathrm{C}$ followed by 35 cycles of $30 \mathrm{~s}$ at $94^{\circ} \mathrm{C}$, then $30 \mathrm{~s}$ at $53^{\circ} \mathrm{C}$ for NZAH-F $4+16 \mathrm{~S}-\mathrm{B}$, or $59^{\circ} \mathrm{C}$ for $16 \mathrm{~S}-\mathrm{A}+\mathrm{NZAH}-\mathrm{R} 1,1.5 \mathrm{~min}$ at $72^{\circ} \mathrm{C}$ and a final extension of $5 \mathrm{~min}$ at $72^{\circ} \mathrm{C}$ in a Perkin Elmer GeneAmp 9600 thermal cycler (Applied Biosystems) or a TGradient thermal cycler (Biometra). All amplifications were done with 10 to $50 \mathrm{ng}$ of genomic DNA in $25 \mu \mathrm{l}$ reactions and checked by agarose gel electrophoresis for the presence of PCR products.

DNA sequencing. Amplified products were cloned into a plasmid vector PCR2.1 using the TA cloning kit (Invitrogen Life Technologies) following the manufacturer's protocol. The cloned DNA inserts were sequenced on an automated sequencer by simultaneous bi-directional cycle-sequencing using the Thermo Sequenase sequencing kit (Amersham Life Science) and M13 forward and reverse infrared-labeled primers (LICOR) following the manufacturer's protocol. Sequencing reactions were electrophoresed and detected on a LI-COR automated sequencer (Model 4200L).

Phylogenetic analyses. SSU rRNA gene sequences were subjected to BLAST searches (Altschul et al. 1990) of the National Center for Biotechnology Information (NCBI) GenBank database to determine whether they were of host or parasite origin. Sequences were aligned for pairwise distance comparisons and phylogenetic analysis using the CLUSTALW algorithm (Thompson et al. 1994) in the MacVector 7.0 DNA sequence analysis software package (Oxford Molecular) using a variety of open- and extend-gap penalties in the ranges of 4 to 20 and 2 to 10 , respectively. The alignments were compared to secondary structure based alignments of a subset of sequences performed at the Ribosomal Database Project II website (see http://rdp.cme.msu.edu/html/, Maidak et al. 2001). It was noted that in the SSU rDNA sequences, there were large inserted regions for a few of the included taxa, which confounded alignment. Therefore, these regions, constituting a total of 254 sites, 
were removed from the analysis. Final analysis was conducted on an alignment of 2345 sites generated with open-gap penalties of 8 and 7 and extend-gap penalties of 3 and 2 for the pairwise and multiple alignment phases, respectively. Parsimony jackknife analysis with 100 random additions of 100 jackknife replicates and determination of the uncorrected (' $p$ ') distances were performed using PAUP*4b8.0 (Swofford 2001). The protistan and invertebrate sequences included in the analysis, along with their respective GenBank accession numbers, are listed in Table 1.

\section{RESULTS AND DISCUSSION}

Using the primers 16S-A and UroComp280SSU, a small DNA fragment (226 bp, excluding primer sequences) was amplified from genomic DNA isolated from epipodium tissue of the first 2 parasite-infected individuals. In a BLAST search of GenBank, this fragment most closely matched the SSU rRNA gene sequences of Urosporidium crescens and Haplosporidium nelsoni. This fragment was presumed to be from parasite DNA. No PCR product was obtained using the general haplosporidian HAP primers for amplification. These primers are useful for amplification of SSU rDNA from most organisms in the genera Bonamia, Haplosporidium, and Minchinia, but not for phylogenetically basal haplosporidians such as Urosporidium. Initially, only abalone sequences were amplified by PCR with the universal SSU rRNA gene primers on DNA from these individuals, as well as with DNA from 3 other infected hosts. Subsequently, we obtained epipodium tissue samples from 3 additional infected individuals and again did PCR with the universal primers in an attempt to obtain a nearly full-length SSU rRNA gene sequence for the parasite. Although most nearly full-length clones were found to contain abalone DNA fragments (10 of 12 clones sequenced), 2 clones contained a haplosporidian-like SSU rRNA gene sequence. The nearly full-length sequence revealed that there were 3 nucleotide differences between the Uro-

Table 1. Taxa included in phylogenetic analysis, and the GenBank accession numbers (acc. no.) of their small-subunit rRNA (SSU rRNA) gene sequences. The New Zealand abalone parasite and Haliotis iris sequences done for this study are shown in bold

\begin{tabular}{|c|c|c|c|}
\hline Taxon & SU rRNA gene GenBank acc. no. & Taxon & SSUrRNA gene GenBank acc. no. \\
\hline Bonamia ostreae & AF192759 & Perkinsus atlanticus & AF140295 \\
\hline Bonami ostreae & AF262995 & Perkinsus chesapeaki & $\mathrm{AF} 042707$ \\
\hline Bonamia exitiosus & AF337563 & Hematodinium sp. & AF286023 \\
\hline Minchinia teredinis & U20319 & Amphidinium carterae & AF009217 \\
\hline Haplosporidium nelsoni & U19538 & Pfiesteria piscicida & AF077055 \\
\hline Haplosporidium costale & AF387122 & Prorocentrum minimum & Y16238 \\
\hline Haplosporidium louisiana & U47851 & Alexandrium fundyense & U09048 \\
\hline Urosporidium crescens & U47852 & Gonyaulax spinifera & AF052190 \\
\hline NZ abalone parasite & AF492442 & Symbiodinium corculorum & L13717 \\
\hline Chondrus crispus & Z14140 & Euplotes crassus & AY007438 \\
\hline Fucus distichus & M97959 & Oxytricha nova & X03948 \\
\hline Ochromonas danica & M32704 & Oxytricha trifallax & AF164121 \\
\hline Achlya bisexualis & M32705 & Entodinium caudatum & U57765 \\
\hline Phytophthora megasperma & X54265 & Frontonia vernalis & U97110 \\
\hline Labyrinthula sp. & AB022105 & Paramecium tetraurelia & X03772 \\
\hline QPX & AF261664 & Tetrahymena pyriformis & M98021 \\
\hline Ulkenia profunda & L34054 & Tetrahymena thermophila & X56165 \\
\hline Pneumocystis carinii & S83267 & Dictyostelium discoideum & X00134 \\
\hline Ajellomyces capsulatus & Z75307 & Entamoeba histolytica & X65163 \\
\hline Neurospora crassa & X04971 & Tritrichomonas foetus & M81842 \\
\hline Kluyveromyces lactis & X51830 & Naegleria fowleri & U80059 \\
\hline Saccharomyces cerevisiae & J01353 & Physarum polycephalum & $\mathrm{X} 13160$ \\
\hline Candida glabrata & X51831 & Trypanosoma cruzi & X53917 \\
\hline Emiliania huxleyi & M87327 & Euglena gracilis & M12677 \\
\hline Chlamydomonas reinhardtii & M32703 & Encephalitozoon cuniculi & L17072 \\
\hline Nitella flexilis & U05261 & Vairimorpha necatrix & Y00266 \\
\hline Acanthamoeba palestinensis & L09599 & Giardia lamblia & M54878 \\
\hline Babesia bovis & L19078 & Diodora graeca & AF120513 \\
\hline Theileria parva & L02366 & Batillus cornutus & AF165311 \\
\hline Eimeria tenella & U40264 & Monodonta labio & X94271 \\
\hline Sarcocystis hominis & AF006470 & Nordotis discus & AF082177 \\
\hline Toxoplasma gondii & U03070 & Haliotis iris & AF492441 \\
\hline Perkinsus marinus & AF042708 & Crassostrea virginica & $\mathrm{X} 60315$ \\
\hline
\end{tabular}




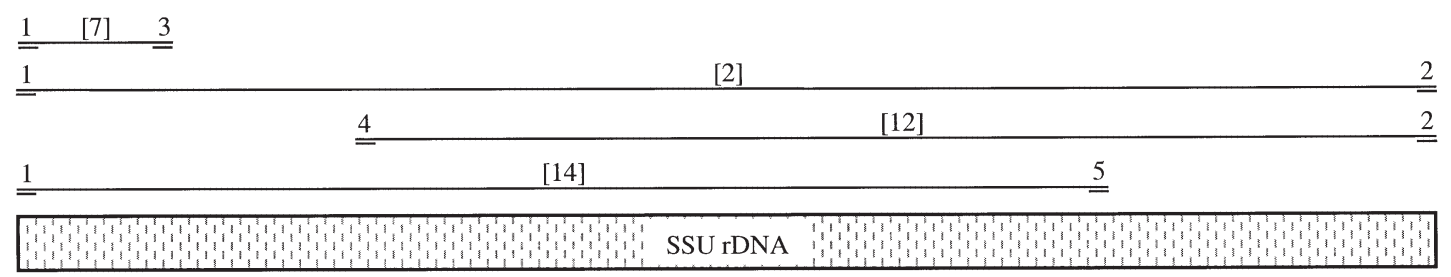

Fig. 1. Locations of PCR primers on the small-subunit rRNA (SSU rRNA) gene, with number of haplosporidian clones sequenced for each PCR product indicated in square brackets. Primers indicated are: (1) 16S-A; (2) 16S-B; (3) UroComp280SSU; (4) NZAHF4; (5) NZAH-R1

Comp280SSU primer that was successfully used to amplify the parasite DNA, initially and the actual sequence of the SSU rDNA. The differences were at positions 2, 15 and 16 in the $21 \mathrm{bp}$ primer length and evidently did not affect the ability of the primer to successfully bind to the parasite SSU rDNA targeted region under the $\mathrm{PCR}$ reaction conditions used for the 16S-A and UroComp280SSU amplification. Based on the sequence of these 2 nearly full-length clones, primers specific to the abalone parasite SSU rDNA were designed (NZAH-F4 and NZAH-R1). These primers were used in PCR to obtain additional amplification products that were cloned and sequenced to complete and confirm the parasite SSU rRNA gene sequence. Overall, 35 clones of various PCR fragments from the 5 infected abalone were sequenced and found to contain haplosporidian-like sequences (Fig. 1).

The SSU rRNA gene fragment presumed to be from the parasite was $1967 \mathrm{bp}$ in length after removal of the primer sequences (GenBank Accession No. AF492442). A single polymorphic site with either an A or $\mathrm{G}$ at Position 605 was detected; however, most of the sequences had $\mathrm{G}$ at this position. Both variants of the sequence were isolated from a single host. GenBankdeposited haplosporidian SSU rDNA sequences ranged in length from $1702 \mathrm{bp}$ for Haplosporidium louisiana to $1831 \mathrm{bp}$ for Urosporidium crescens. Uncorrected (' $\mathrm{p}$ ') pairwise distances were calculated for all haplosporidian sequences and the abalone parasite sequence, following alignment and removal of ambiguously aligned regions. For previously deposited GenBank haplosporidian sequences, pairwise distances ranged from 0.018 to 0.252 . The greatest distance was observed between $U$. crescens and $H$. louisiana ('p' $=0.252$ ), while the Bonamia ostrea and $B$. exitiosus sequences were most similar (' $\mathrm{p}$ ' $=0.018$ ). The pairwise distances between the abalone parasite SSU rDNA sequence and the haplosporidian sequences ranged from 0.123 to 0.252. The parasite SSU rRNA gene sequence was most similar to that of $U$. crescens (' $p$ ' $=0.123$ ), and the greatest distance was observed between the parasite and $H$. louisiana (' $\mathrm{p}$ ' = 0.252).
Parsimony analysis of host and protistan SSU rRNA gene sequences was conducted to examine the taxonomic affinities of this abalone parasite. The gene sequences of many marine parasites such as parasitic dinoflagellates, labyrinthulomycetes, Perkinsus species and haplosporidians were included in the analysis (Table 1). Of 2345 sites in the aligned sequences, 1215 were parsimony-informative. Parsimony jackknife analysis grouped the parasite sequence obtained in this study with a monophyletic haplosporidian clade with $98 \%$ support (Fig. 2). The black-footed abalone parasite fell at the base of the Haplosporidia, grouping with Urosporidium crescens. The phylogenetic analysis suggested that Haplosporidium, Minchinia and Bonamia species were all more recently evolved taxa within the phylum. The haplosporidian sequences, however, did not group with alveolate sequences in this study, as reported in earlier molecular phylogenetic analyses (Siddall et al.1995, Flores et al. 1996). In addition, the gene sequence that was presumed to be from the black-footed abalone genome grouped with gastropod SSU rRNA gene sequences (GenBank Accession No. AF492441).

Overall, the molecular analyses presented here strongly supported previous morphological and ultrastructural observations (Hine et al. 2002, Diggles et al. 2002), which suggested that the parasite found in the New Zealand black-footed abalone was a haplosporidian. The SSU rRNA gene sequence data indicated that this parasite was a basal member of the phylum Haplosporidia, as it grouped with the haplosporidians at the base of the clade in phylogenetic analysis. This result was consistent with the ultrastructural characteristics of haplosporidians identified in this parasite, such as multinucleate plasmodia, mitochondria with tubular cristae, anastomosing endoplasmic reticulum, and haplosporosome-like bodies produced from nuclear membranebound Golgi that matured to haplosporosomes (Hine et al. 2002). Additionally, in situ hybridisation using a DNA probe designed to detect SSU rRNA of Bonamia ostreae exhibited 'moderately strong reactions' with plasmodia of this parasite (Diggles et al. 2002). To date, spores have not been successfully isolated and characterized 
(B. Diggles \& P. M. Hine pers. comm.). Scanning electron microscope analysis of spores, if available, as well as molecular phylogenetic analyses on other gene se- quences, would help to determine whether this parasite is a member of an existing genus or should be assigned to a new genus in the phylum Haplosporidia.

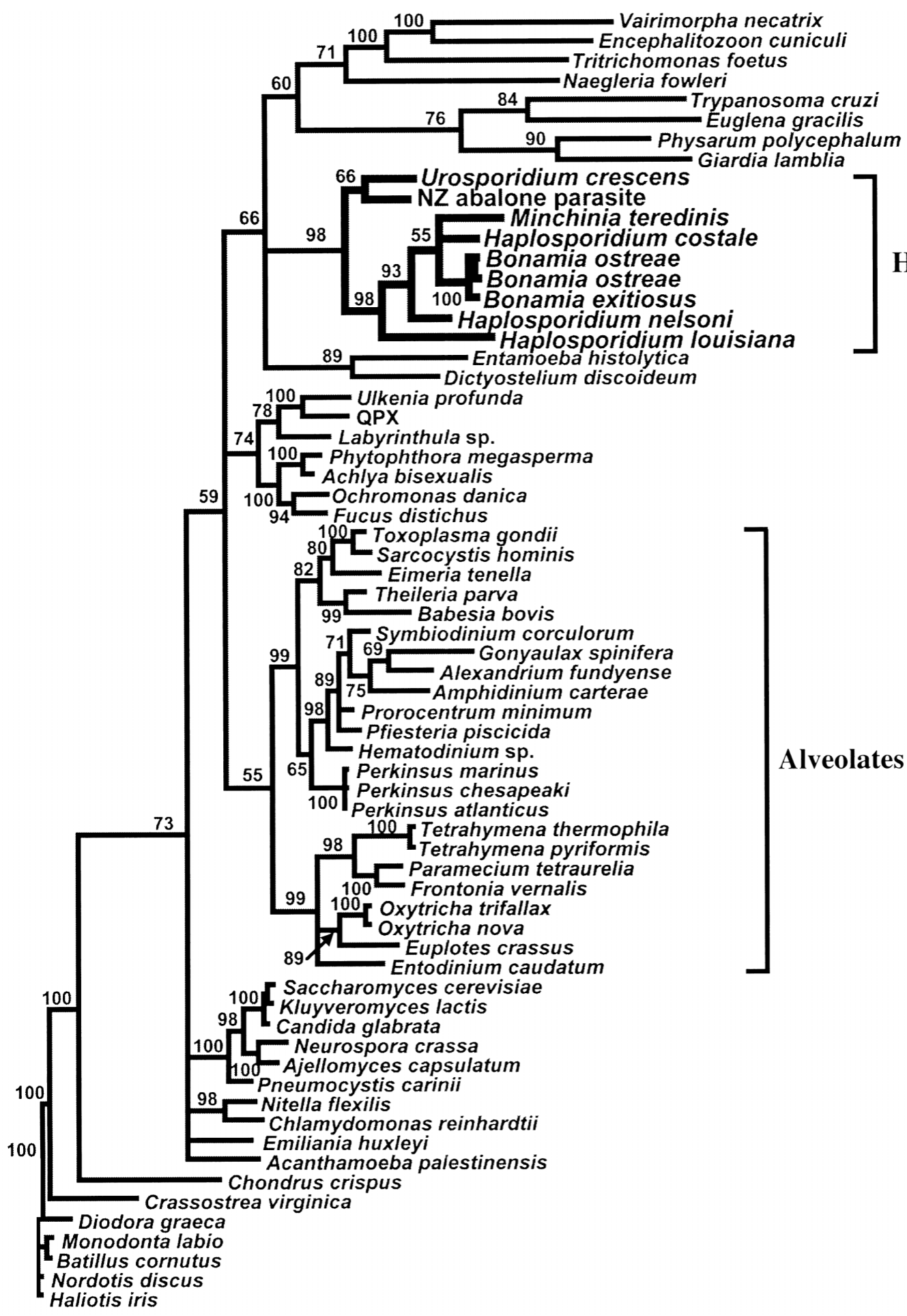

Haplosporidians

Fig. 2. Parsimony jackknife tree generated based on the near complete small-subunit rDNA (SSU rDNA) sequences. Jackknife support values above 50 are shown on branches. Analysis was done with 100 jackknife replicates of 100 random additions and gaps were treated as missing data 
Acknowledgements. The authors thank Ben Diggles and Carolyn Friedman for infected abalone samples, Kathleen Apakupakul for technical assistance and Eugene Burreson, Ben Diggles and Mike Hine for critical review of the manuscript. VIMS contribution number 2478.

\section{LITERATURE CITED}

Altschul SF, Gish W, Miller W, Myers EW, Lipman DJ (1990) Basic local alignment search tool. J Mol Biol 215:403-410

Andrews JD (1966) Oyster mortality studies in Virginia. V. Epizootiology of MSX, a protistan pathogen of oysters. Ecology 47:19-31

Andrews JD, Wood JL, Hoese HD (1962) Oyster mortality studies in Virginia. III. Epizootiology of a disease caused by Haplosporidium costale Wood and Andrews. J Insect Pathol 4:1327-343

Annala JH, Sullivan KJ, O'Brien CJ (2000) Report from the Fishery Assessment Plenary, May 2000: stock assessments and yield estimates. Ministry of Fisheries report, National Institute of Water and Atmospheric Research library, Wellington

Burreson EM, Stokes NA, Friedman CS (2000) Increased virulence in an introduced pathogen: Haplosporidium nelsoni (MSX) in the eastern oyster Crassostrea virginica. J Aquat Anim Health 12:1-8

Carnegie RB, Barber BJ, Culloty SC, Figueras AJ, Distel DL (2000) Development of a PCR assay for detection of the oyster pathogen Bonamia ostreae and support for its inclusion in the Haplosporidia. Dis Aquat Org 42:199-206

Cochennec N, Le Roux F, Berthe F, Gerard A (2000) Detection of Bonamia ostreae based on small subunit ribosomal probe. J Invertebr Pathol 76:26-32

Diggles BK, Nichol J, Hine PM, Wakefield S, Cochennec-Laureau N, Roberts RD, Friedman CS (2002) Pathology of cultured paua Haliotis iris infected with a novel haplosporidian parasite, with some observations on the course of disease. Dis Aquat Org 50:219-231

Elston RA, Farley CA, Kent ML (1986) Occurrence and significance of bonamiasis in European flat oysters Ostrea edulis in North America. Dis Aquat Org 2:49-54

Flores BS, Siddall ME, Burreson EM (1996) Phylogeny of the Haplosporidia (Eukaryota: Alveolata) based on small subunit ribosomal RNA gene sequence. J Parasitol 82: 616-623

Ford SE, Haskin HH (1982) History and epizootiology of Haplosporidium nelsoni (MSX), an oyster pathogen in Delaware Bay, 1957-1980. J Invertebr Pathol 40:118-141

Friedman CS, Perkins FO (1994) Range extension of Bonamia ostreae to Maine, USA. J Invertebr Pathol 64:179-181

Friedman CS, Andree KB, Beauchamp KA, Moore JD, Robbins TT, Shields JD Hedrick RP (2000) 'Candidatus Xenohaliotis californiensis', a newly described pathogen of abalone, Haliotis spp., along the west coast of North America. Int J Syst Evol Microbiol 50:847-855

Gardner GR, Harshbarger JC, Lake JL, Sawyer TK, Price KL, Stephenson MD, Haaker PL, Togstad HA (1995) Association of prokaryotes with symptomatic appearance of withering syndrome in black abalone Haliotis cracherodii. J Invertebr Pathol 66:111-120

Goggin CL, Lester RJG (1995) Perkinsus, a protistan parasite of abalone in Australia: a review. Mar Freshw Res 46: $639-646$

Editorial responsibility: Carey Cunningham,

Aberdeen, Scotland, UK
Grindley RM, Keogh JA, Friedman CS (1998) Shell lesions in New Zealand Haliotis sp. (Mollusca, Gastropoda). J Shellfish Res 17:805-811

Hine PM (1991) Ultrastructural observations on the annual infection pattern of Bonamia sp. in flat oysters Tiostrea chilensis. Dis Aquat Org 11:163-171

Hine PM, Wesney B (1992) Interrelationships of cytoplasmic structures in Bonamia sp. (Haplosporidia) infecting oysters Tiostrea chilensis: an interpretation. Dis Aquat Org 14: $59-68$

Hine PM, Cochennec-Laureau N, Berthe FCJ (2001) Bonamia exitiosus n. sp. (Haplosporidia) infecting flat oysters Ostrea chilensis in New Zealand. Dis Aquat Org 47:63-72

Hine PM, Wakefield S, Diggles BK, Webb VL, Maas EW (2002) The ultrastructure of a haplosporidian containing Rickettsiae, associated with mortalities among cultured paua Haliotis iris. Dis Aquat Org 49:207-219

Katkansky SC, Dahlstrom WA, Warner RW (1969) Observations on survival and growth of the European flat oyster, Ostrea edulis, in California. Calif Fish Game 55:69-74

Lester RJG, Davis GHG (1981) A new Perkinsus species (Apicomplexa, Perkinsea) from the abalone Haliotis ruber. J Invertebr Pathol 37:181-187

Maidak BL, Cole JR, Lilburn TG, Parker CT Jr and 6 others (2001) The RDP-II (Ribosomal Database Project). Nucleic Acids Res 29:173-174

Medlin L, Elwood HJ, Stickel S, Sogin ML (1988) The characterization of enzymatically amplified eukaryotic 16S-like rRNA-coding proteins. Gene 71:491-499

Nakatsugawa T, Nagai T, Hiya K, Nishizawa T, Muroga K (1999) A virus isolated from juvenile black abalone Nordotis discus discus affected with amyotrophia. Dis Aquat Org 36:159-161

Perkins FO (1971) Sporulation in the trematode hyperparasite Urosporidium crescens De Turk, 1940 (Haplosporida: Haplosporidiidae) an electron microscope study. J Parasitol 57:9-23

Pichot Y, Comps M, Tige G, Grizel H, Rabouin MA (1980) Recherches sur Bonamia ostreae gen. n., sp. n., parasite nouveau de l'huître plate Ostrea edulis L. Rev Trav Inst Pech Marit 43:131-140

Reece KS, Burreson EM, Bower SM, Dungan CF (2000) Molecular analyses of a parasite in prawns (Pandalus platyceros) from British Columbia, Canada. J Shellfish Res 19: 647

Renault T, Stokes NA, Chollet B, Cochennec N, Berthe F, Burreson EM (2000) Haplosporidiosis in the Pacific oyster, Crassostrea gigas, from the French Atlantic coast. Dis Aquat Org 42:207-214

Siddall ME, Stokes, NA, Burreson EM (1995) Molecular phylogenetic evidence that the phylum Haplosporidia has an alveolate ancestry. Mol Biol Evol 12:573-581

Stokes NA, Siddall ME, Burreson EM (1995) Detection of Haplosporidium nelsoni (Haplosporidia: Haplosporidiidae) in oysters by PCR amplification. Dis Aquat Org 23: $145-152$

Swofford DL (2001) PAUP*: phylogenetic analysis using parsimony ( ${ }^{*}$ and other methods), Version 4. Sinauer Associates, Sunderland, MA

Thompson, JD, Higgins DG, Gibson, TJ (1994) Improving the sensitivity of progressive multiple sequence alignment through sequence weighting, position-specific gap penalties and weight matrix choice. Nucleic Acids Res 22: $4673-4680$ 